\title{
JEJAK KEBUDAYAAN AUSTRONESIA DI PANTAI TIMUR SUMATERA SELATAN
}

\author{
Oleh: Brian Apriadi*, Dimas Setiawan*, Eva Dina Chairunisa** \\ *Mahasiswa Program Studi Pendidikan Sejarah Universitas PGRI Palembang \\ *Dosen Program Studi Pendidikan Sejarah Universitas PGRI Palembang
}

\begin{abstract}
ABSTRAK
Bangsa Austronesia mulai memasuki wilayah Indonesia disebut sebagai bangsa Proto Melayu. Masyarakat Austronesia mulai berkembang dan bermigrasi ke Sumatera dengan tujuan Pantai Timur Sumatera Selatan yang memiliki kontur tanah rawa rawa basah dan sangat sulit digunakan baik untuk pertanian maupun perkebunan. Selain itu juag kebudayaan mereka di daerah pantai timur masih dugunakan samapai dengan sekarang. Tujuan Dalam penelitian ini adalah untuk mengetahui bentukbentuk Kebudayaan Asutronesia Di Pantai Timur Sumatera Selatan Sebagai Sumber Pembelajaran Sejarah. Bentuk penelitian ini deskriptif kualitatif. Hasil penelitian ini dapat disimpulkan bahwa. Kebudayaan austronesia di pantai timur sumatera selatan masih dipakai hingga saat ini berupa dari sistem pengelolaan lingkungan, sistem perternkan, sistem perkapala/alat trasportasi, dan juga sistem pengelolaan bahan makanan yang sekarang masih lestari dan masih dijaga oleh masyarakat yang ada disana.
\end{abstract}

Kata Kunci: Kebudayaan, Austronesia, Pantai Timur Sumatera Selatan.

\section{A. PENDAHULUAN}

Indonesia adalah Negara kepulauan terbesar didunia sehingga Indonesia disebut dengan Nusantara (kepulauan antara), sehingga Indonesia banyak dipengaruhi oleh bangsa lainnya. Kepulaun Indonesia menjadi wilayah perdagangan penting setidaknya sejak abad ke 7, yaitu ketika kerajaan Sriwijaya di Palembang menjalin hubungan agama dan perdagangan dengan Tiongkok dan India (Hadi, 2011:66). Indonesia terletak antara $5054^{\prime}$ lintang Utara dan $11^{0}$ lintang Selatan, serta $95^{\circ} 01^{\prime}$ bujur Timur dan 1410 02' bujur Timur. Itulah sebabnya Indonesia termasuk daerah khatulistiwa dan berada di daerah hembusan angin musim Indo-Australia. Ciri iklimnya ialah berhawa tropis dengan curah hujan yang tinggi. Keadaan iklim yang yang dipengaruhi oleh angin musim menyebabkan adanya musim kemarau dan penghujan. Panjang pendek musim-musim itu berada menurut letak daerahnya.di kepulaun Indonesia. Misalnya pada pola pertanian, pola pelayaran, dan aspek-aspek lain yang yang dipengaruhi iklim. Angin musim jelas berpengaruh pada pola pelayaran. Pada gilirannya ia memengaruhi berbagai kegiatan yang dilaksanakan dengan perahu (Poesponegoro, 2010:01).

Secara garis besar Indonesia terletak pada pertemuan dua sistem Geosinklin Tethys dan Geodinklin sirkum Pasifik. Kedua Geosinklin ini mempunyai pengaruh penting terhadap morfologi kepulauan Indonesia pada zaman-zaman berikutnya serta mengakibatkan Indonesia mempunyai struktur geologi yang kompleks (Sriyono, 2014: 48).

Sumatera adalah pulau terbesar di kawasan Hindia Timur yang membentuk batas wilayah paling barat kepulaun Nusantara. Mengenai nama sumatera, dapat disimpulkan bahwa nama tersebut tidak diketahui, baik oleh pengembara Arab maupun Marco polo. Kemungkinan besar mereka tidak dapat informasi mengenai nama itu dari penduduk lokal primitive yang dijumpainya (Marsden, 2013:2-11). 
Nama-nama lain yang sering juga diberikan terhadap pulau ini adalah Swarnabhumi, Java Minor, pulau Perca, dan pulau Andalas.Sawrnabhumi adalah nama yang diberikan oleh Adityawarman, raja Minangkabau pada abad ke-14. Java Minor adalah nama yang diberikan oleh Marco Polo dan dua nama terakhir diberikan oleh penduduk pribumi yang mendiami pulau ini. Pulau Sumatera dikelilingi oleh beberapa teluk, selat, dan laut. Disebelah Utara terdapat teluk Benggala yang memisahkannya dengan anak benua India. Disebelah Timur terdapat selat Malaka dan selat Bangka yang memisahkanya dengan Semenanjung Malaysia dan pulau Bangka disebelah Selatan terdapat selat Sunda yang memisahkannya dengan pulau Jawa dan sebelah Barat terhampar Samudera Hindia (Asnan, 2006:18).

Bentuk dari pulau Sumatera adalah memanjang dengan ukurannya $1.650 \mathrm{~km}$ dan lebarnya antara 100-200 km dibagian Utara serta sekitar $350 \mathrm{~km}$ di bagian Selatan. Di ujung Selatan pulau Sumatera terdapat dua teluk yang menjorok ke daratan yaitu teluk Lampung dan teluk Semangko. Di pantai Timur banyak sungaisungai besar mengendapkan lumpur, sehingga memperluas daratan. Di sisi sebelah Timur Sumatera terdapat pulaupulau yang berawa-rawa seperti Rupat, Bengkalis, Padang Tebing Tinggi, Rangsang pulau-pulau tersebut dipisahkan oleh selat yang sempit dan dangkal (Sriyono, 2014:80).

Sumatera Selatan merupakan salah satu kepulauan terbesar di Indonesia yang memiliki kekayaan budaya yang beragam di setiap kabupaten atau kota dengan satu dengan yang lainnya hampir berbeda (Utomo, 2016:123). Dalam peta Sejarah Indonesia, Sumatera Selatan memiliki Sejarah yang panjang. Didasarkan bendabenda peninggalan sejarah di Sumatera Selatan dapat diketahui bahwa bahwa daerah itu telah muncul dua bentuk sistem kekuasaan yang menonjol yaitu kerajaan
Sriwijaya abad ke 7-13 M dan Kesultanan Palembang pada abad ke 17-19 M (Supriyanto, 2013:01).

Secara geografis Sumatera Selatan berbatasan dengan Provinsi Jambi, dan Kepulauan Bangka Belitung di Timur berbatasan dengan Provinsi Lampung, di Selatan Bengkulu di Barat. Masyarakat Sumatera Selatan sangat menjaga hubungan sosial karena didasari semangat kebangsaan, walaupun dalam kehidupan sehari-hari sangat mempengaruhi adat istiadat. Rumah adat dari Provinsi Sumatera Selatan yaitu rumah limas serta suku yang mendiami wilayah Sumatera Selatan yaitu suku Melayu yang terdiri dari suku Melayu Palembang, Pasemah, Lematang, Musi Banyuasin serta Semendo selain suku Melayu terdapat juga suku Jawa, Komering, serta Sunda. Sehingga dapat kebudayaan Sumatera Selatan menjadi kaya serta unik (Supriyanto, 2013:31-32).

Kawasan pesisir Timur pulau Sumatera dilihat dari sudut pandang geohistoris memiliki prosisi yang sangat strategis dan sangat berpengaruh dalam membentuk konfigurasi persebaran situssitus pemukiman di Sumatera. Kedudukannya berada di jalur pelayaran antara India dan Cina telah memungkinkan daerah-daerah pesisir di wilayah ini menjadi temapt persinggahan para pedagang dari barat ke timur serta sebaliknya (Poeponegoro, 2010:65).

Pantai Timur Sumatera Selatan merupakan wilayah yang sangat strategis lokasinya karena berhadapan dengan jalur perdagangan kuno mulai dari masa praSriwijaya sampai dengan masa Kesultanan Palembang Darussalam. Kawasan pantai Timur Sumatera Selatan telah menjalin hubungan dengan dunia luar. Di daerah pantai Timur Sumatera Selatan terdapat banyak situs-situs sejarah (Siddhayatra, volume 19 nomor 2 2014:87).

Kebudayaan merupakan suatu aspek evolusi manusia yang kemudian menyebabkan bahwa ia dapat lepas dari 
alam kehidupan mahluk primata yang lain, kebudayaan yang berwujud gagasan dan tingkah laku manusia keluar dari otak dan tubuhnya, tidak terlepas dari keperibadian individu melalui suatu proses belajar yang panjang, menjadi milik masing-masing individu warga masyarakat yang bersangkutan(Koenjaraningrat, 2009:180).

Terutama di Indonesia memiliki berbagai macam budaya salah satunya yaiu budaya Austronesia budaya Austronesia merupakan kehidupan sukusuku bangsa peternak berpindah-pindah dari suatu perkemahan lain dengan mengembala ternak mereka menurut musim-musim tertentu, mereka memerah susu ternak lalu membuat menjadi mentega, keju, dan hasil olahan lain dari susu yang dapat disimpan lama. Selama berpindahpindah meraka harus menjaga ternak mereka dengan baik agar tidak dicuri oleh kelompok-kelompok ternak lainnya. Jumlah ternak yang mereka miliki sering kali mencapai ratusan ekor sapi atau domba, kehidupan seperti itu menyababkan bahwa bangsa-bangsa peternak itu sering sangat agresif sifatnya (Koenjaraningrat, 2009:218).

Suku-suku bangsa Austronesia berusaha menjinakkan berbagai jenis hewan seperti sapi, kerbau, domba, onta, dan rendeer (rusa kutub), adapun hewan-hewan yang mereka manfaatkan sebagi pembantu pekerjaan seperti anjing, kerbau, babi, kuda dan ilama. Mengembangkan hewan-hewan ternak mula-mula untuk kepentingan kegiatan sehari-hari dalam arti untuk diminum susunya dan dimakan dagingnya,kemudian berkembang menjadi kebiasaan untuk memanfaatkan susu, mentega, keju, kulit, dan bulu hewan ternak yang melengkapi peradaban bangsa peternak. Alam peternakan tersebut merangsang jenis keterampilan lainnya, seperti menemukan roda yang memudahkan pengangkutan (Soekmono, 1973:58).
Hal ini menyebabkan bangsa Austronesia sudah mengenal berbagai jenis peralatan kehidupan untuk mendukung aktivitas mereka. Dalam mengembangbiakkan binatang peliharaan mereka seperti sapi, kerbau, onta dan lainnya dibutuhkan teknologi dalam perkembangan kebudayaan. Bangsa austronesia yang tinggal di pantai Timur Sumatera telah mengenal banyak sekali teknologi pendukung kehidupan mereka. Karena keadaan alam mereka yang memaksa mereka untuk mengembangkan teknologi seperti teknologi rumah, perkapalan peternakan dan teknologi teknologi lain.

Berdasarkan uraian diatas maka peneliti tertarik untuk mengetahui jejak kebudayaan Austronesia yang masih ada di tempat lokasi yang akan diteliti oleh peneliti. Dari pokok bahasan diatas maka permasalahan ini bagaimanakah jejak kebudayaan Austronesia di pantai timur Sumatera Selatan sebagai sumber pembelajaran sejarah?

\section{B. METODE PENELITIAN}

Metode yang digunakan adalah metode deskriptif kualitatif.

\section{Teknik Pengumpulan Data}

Pengumpulan data dapat dilakukan dalam berbagai seting, berbagai sumber, dan berbagai cara. Pengumpulan data berdasarkan tekniknya yaitu melalui: observasi, dokumentasi dan wawancara .

Observasi: Mendatangi tempat lokasi penelitian dan melihat apa yang menjadi permasalahan di lapangan.

Wawancara: Digunakan sebagai teknik pengumpulandata apabila peneliti ingin melakukan studi pendahuluan untuk menemukan permasalahan yang harus diteliti.

Dokumentasi: Dokumentasi digunakan untuk mendapatkan data yang ada dilapangan seperti arsip, foto, dan dokumen yang menyimpan tentang penelitian. 


\section{HASIL DAN PEMBAHASAN}

1. Kedatangan Bangsa Austronesia

Austronesia sebenarnya adalah ciptaan para sarjana ketika mereka harus menjelaskan adanya kebudayaan awal dalam masa para sejarah yang berkembang di kawasan Asia Tenggara. Bukti-bukti adanya kebudayaan para sejarah yang mempunyai kemiripan dengan Kepulauan Indonesia, Philipina, Taiwan, Kepulauan Pasifik hingga Kepulauan Fiji dan ke Barat bukti-bukti tersebut dapat ditemukan hingga kepulauan Madagaskar di Pantai Timur Afrika (Munandar, 2012:1).

Pulau-pulau yang berada di sebelah Selatan daratan Asia lazim disebut Austronesia (Austro=Selatan dan Nesos=pulau). Bangsa ini mendiami daerah yang luas, yaitu meliputi daerah-daerah yang membentang antara Madagaskar di sebelah Barat, hingga pulau Paskah di sebelah Timur dan Formosa atau Taiwan di sebelah Utara sampai Selandia Baru di Selatan (Soekmono, 1973:58).

Bangsa Austronesia yang memasuki wilayah Indonesia disebut sebagai bangsa Proto Melayu. Mereka inilah sebagai nenek moyang langsung bangsa Indonesia sekarang. Itu merupakan ras campuran antara ras Mongoloid dan Melayu, dari hasil campuran tersebut kemudian lahirlah bangsa Proto Melayu (Melayu Tua) dan Deutero Melayu (Melayu Muda). Melayu Tua, datang pada gelombang pertama dan menjadi suku-suku bangsa yang saat ini tinggal di daerah pedalaman, seperti suku Batak di Sumatera Utara, suku Dayak di Kalimantan, dan suku Toraja di Sulawesi. Semantara Melayu Muda datang belakangan (gelombang kedua) dan menjadi cikal bakal suku-suku Jawa, Sunda, Bali, di samping sejumlah suku-suku yang mendiami wilayah pesisr pulau-pulau basar di atas (Herimanto, 2012:76-77).

Pendapat yang populer adalah tentang "Out Of Taiwan" yang menyatakan tempat asal orang Austronesia adalah Taiwan. Pendapat ini sudah di kemukakan oleh Robert Blust berdasarkan kajian terhadap bahasa-bahasa dalam rumpun Austronesia. la juga mengadakan kajian terhadap flora, fauna dan gejala alam lainnya. Maka, kesimpulannya adalah tempat asal penutur bahasa Austronesia adalah Taiwan (Samanto, 2011:263).

\section{Kebudayaan Austronesia di Pantai Timur Sumatera Selatan}

Masyarakat Austronesia mulai berkembang dan bermigrasi ke Sumatera dengan tujuan Pantai Timur Sumatera Selatan yang memiliki kontur tanah rawa rawa basah dan sangat sulit digunakan baik untuk pertanian maupun perkebunan. Selain itu juga terdapat pertemuan bukit bukit yang tidak bisa dibuka tetapi digunakan sebagai aliran air dan daerah cekungan yang tidak bisa dirubah dibiarkan ditumbuhi semak belukar. Di pantai Timur Sumatera Selatan terdapat tradisi masyarakat yang membuat suatu sistem yang memanfaatkan keadaan lingkungan adar tidak merusak alam disebut Repangan. Repangan adalah sistem pengolahan tanaman dengan cara percampuran antar tanaman buah dengan tanaman hutan dengan cara pembukaan lahan dengan meninggalkan batang atau pohon yang baik dengan nilai ekonomis tinggi, fungsinya adalah sebagai cadangan untuk pembuatan rumah, kapal dan lainnya. Adapun campuran dari pohon hutan dan pohon buah adalah sebagai berikut:

\begin{tabular}{|l|l|}
\hline Tanaman Hutan & Tanaman Buah \\
\hline gaharu & duku \\
\hline pulai & durian \\
\hline sungkai & rambai \\
\hline leban & pinang \\
\hline seru & rotan \\
\hline tembesu & jengkol \\
\hline cempako & melinjo \\
\hline pedaro & geunggang \\
\hline & langsat \\
\hline & bambau \\
\hline
\end{tabular}




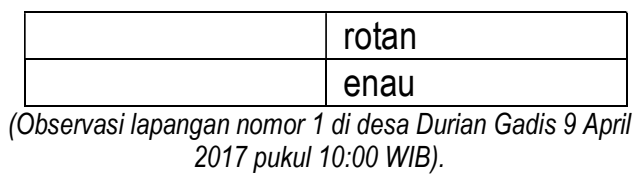

Sebagai akibat dari pemanfaatan lingkungan tersebut menyebabkan banyak hewan asli di pantai Timur Sumatera Selatan terjaga populasinya dengan baik. Banyak hewan hewan yang sekarang pun masih bisa kita jumpai beberapa jenis unggas dan hewan mamalia seperti elang abu abu, pelatuk, sri gunting, elang bondol, bangau, tupai, monyet dan lain lain yang menjadi bukti bahwa masyarakat Austronesia di pantai Timur Sumatera Selatan menjaga alam dengan baik (Observasi lapangan no 1 di desa Durian Gadis 9 April 2017 pukul 10:00 WIB).

Selain itu juga kearifan lingkungan oleh masyarakat Austronesia di pantai Timur Sumatera Selatan sangat berpengaruh terhadap pemanfaatan lingkungan mengenai sistem pembukaan lahan menjadi sawah atau kebun. Pemanfaatan sawah yang masih tersisa di pantai Timur Sumatera Selatan oleh masyarakat Austronesia adalah sistem penanaman padi yang dikenal dengan sistem nyonor atau sonor. Yang dimaksud sistem ini adalah pemanfaatan lahan dengan menanam padi yang sangat sederhana yang dibawa oleh masyarakat Austronesia ke pantai Timur Sumatera Selatan. Sistem ini menggunakan lahan yang sudah dibakar terlebih dahulu agar tanah yang akan ditanam subur karena tanah di pantai Timur Sumatera Selatan merupakan tanah rawa yang kurang bisa dimanfaatan untuk pertanian. Dengan membakar lahan akan menambah kesuburan tanah dan dapat digunakan untuk menanam padi. Teknik penanamannya ialah dengan cara ditaburkan secara sembarang hal itu dikarenakan karena teknologi yang digunakan masyarakat Austronesia masih sangat sederhana (Observasi lapangan no 2 di desa Sako14 April 2017 pukul 13:00 WIB).
Selain memanfaatkan lahan untuk dijadikan sebagai lahan repangan hasil dari repangan ini dimanfaatkan sebgai bahan bku pembuatan kapal dengan bahan baku kayu yang bgaus dan awet untuk dijadikan kapal seperti kayu unglen. Kayu unglen dugunakan sebagai salah satu bahan baku dari pembuatan kapal karena kayu unglen dipilih karena awet dan tahan lama sehingga kayu unglen dipakan sebagai salah satu bahan baku pembuatan kapal.

Kerbau termasuk famili Bovidae pada awal awal keberadaannya telah diternakkan di India, Malaysia dan Mesir. Kerbau jinak (Bubalus bubalis) berasal dari daratan lembah Indus berkisar 4.500 tahun yang lalu, kemudian menyebar ke Cina sekitar 3.500 tahun yang lalu. Salah satu kerbau jinak yaitu kerbau air (Water Bufallo) di daerah tropis dan sub-tropis dikenal dengan beberapa nama seperti Bhains di India, Karabue atau Kwai di Thailand, Carabao di Filipina, Karbo di Malaysia dan kerbau di Indonesia (Wiradnyana, 2011:203).

Kerbau memiliki fungsi sebagai pembajak sawah untuk membantu para petani tetapi tidak banayak yang memelihara kerbau dikarenakan masyarakat yang memelihara dan memiliki kerbau berstatus sosial tinggi di masyarakat. Masyarakat setiap harinya akan melepaskan kerbaunya di pagi hari dan akan dijemput dengan cara digiring. Tempat melepaskan kerbau untuk mencari makan biasanya di padang rumput atau di sekitaran rawa rawa (Observasi lapangan no 2 di desa Durian Gadis 9 April 2017 pukul 08:00 WIB).

Adapun keunikan yang terjadi dari kerbau yaitu masyarakat menggunakan sistem campuran artinya satu kandang yang terdiri dari 8 sampai 10 kerbau, Tetapi tidak milik satu orang tetapi terdiri dari beberapa orang. Sekelompok kerbau terdiri dari 80 sampai 100 ekor kerbau. Kerbau memiliki warna hitam dan bertanduk panjang seperti banteng dimanfaatkan tenaganya untuk membajak sawah. Kandang kerbau yang digunakan berukuran $11,5 \mathrm{~m} \times 8,8 \mathrm{~m}$ 
dengan tinggi 3,5 m. kayu yang digunakan untuk pembuatan kandang kerbau adalah kayu Leban sebagai pondasi yang merupakan kayu asli di pantai timur Sumatera Selatan dan kayu Gelam sebagai rangkanya, selain itu juga atapnya mnggunakan ljuk dan daun Kelapa (Wawancara No 1 Tanggal 9 Februari 2017 Pukul 08:30 WIB).

Kerbau memiliki makna salah satunya terdapat unsur didalam sistem dualisme dimana alam semesta ini dibagi atas dua hal atau dua golongan yang saling bertentangan satu sama lainnya, antara lain dunia bawah dan atas, laki laki dan wanita, alam nyata dan maya dan sebagainya. Begitu juga dengan cara pandang masyarakat masa lalu terhadap kerbau yaitu kerbau dipandang dari dua sisi yaitu sisi fisik dan non fisik. Dalam kaitannya dengan sisi fisik kerbau lebih banyak bermakna sosial ekonomis sedangkan dalam sisi non fisik kerbau memiliki makna simbolis. Mengingat kerbau memiliki peran yang penting maka bentuk binatang kerbau digunakan dalam berbagai aspek diantaranya sosial ekonomi, hukum, religi, dan sebagainya. Sejalan dengan itu berkembang suatu konsepsi terhadap kerbau sebagai binatang suci dan sumber kekuatan magis, menolak kekuatan jahat sehingga kerbau dipakai sebagai hewan kurban untuk upacara persembahan maupun kematian (Wiradnyana, 2011:209).

Sistem teknologi atau cara-cara memproduksi, memakai, dan memelihara segala peralatan hidup dari suku bangsa dalam karangan etnografi, cukup membatasi dri terhadap teknologi yang tradisional, yaitu teknologi peralatan hidupnya yang tidak atau hanya secara terbatas di pengaruhi oleh teknologi yang berasal dari kebudayaan barat (Koenjaraningrat, 2009:263).

Kapal sebagai salah satu alat transportasi yang terbilang tua yang telah banyak dikenal oleh suku bangsa di dunia terutama bangsa Autronesia. Bentuk perahu yang sederhana inilah yang digunakan sebagai alat transportasi perahu juga dapat dibuat dari bermacam bahan seperti batang kayu, bambu. Bentuk perahu yang paling sederhana rupanya yaitu perahu lesung. perahu ini terdiri dari sebuah balok kayu yang dibelah, kemudian dikeruk dalamnya. Perahu-perahu kecil semacam itu tentu hanya dapat dipergunakan di sungai, walaupun demikian ada suku-suku bangsa yang telah mencapai suatu kepandaian untuk menggunakannya hingga jauh ke laut suku-suku bangsa penduduk kepulauan di lautan Teduh malahan mampu menyeberangi lautan dari satu pulau ke pulau lain, dengan jalan memasang cadik pada perahu-perahu lesungnya, ada sukusuku bangsa yang memakai sebuah dan kadang kadang dua sayap bercadik. Cadikcadik tersebut memang memberi keseimbangan pada perahu sehingga tidak mudah terbalik oleh ombak besar (Koenjaraningrat, 2009:273-274).

Selain pembuatan kapal ada juga teknik pembuatan gerobak. Gerobak digunakan sebgai salah satu alat trasportasi yang digunakan untuk mengangkut hasil dari perkebunan yang diangkut melalui jalan darat di pantai Timur Sumatera Selatan, masih ada gerobak tradisional yang diguanakan oleh masyarakat disana sebagai salah satu alat trasportasi darat gerobak juga digunakan untuk mengangkut hasil komoditas yang laku diperjual belikan. Gerobak ditarik menggunakan tenaga kerbau untuk menariknya sehingga dapat berjalan dengan baik. Perkembangan penggunaan gerobak sebagai alat angkut mengalami perubahan hanya sedikit yaitu dibagian roda yang awalnya dari kayu kemudian menjadi ban mobil. Tetapi untuk bentuknya masih mempertahankan bentuk aslinya dengan bahan kayu (Observasi lapangan no 3 tanggal 9 April 2017, pukul 14.30 WIB).

Pantai Timur Sumatera Selatan yang nota bene daerah rawah gambut, yang menyebabkan hasil dari sumber daya alamnya yang melimpah terutama hasil 
tangkapan ikan. Ikan sebagai salah satu hewan yang termasuk kedalam kebutuhan pokok manusia. Sistem pengelolaan makanan yang terdapat di daerah pantai Timur Sumatera adalah sistem pengelolaan makanan berupa pengawetan bahan makanan yang berfungsi sebagai cadangan makanan yang dikemudian hari sewaktuwaktu persediaan makan menipis seperti pengelolaan ikan asin, ikan sale, bekasam, rusip dan lain-lain. Itu sebagai salah satu contoh sistem pengelolaan makanan tradisional yang sudah ada sejarak zaman dahulu. Makanan serupa dijumpai di Tailand dengan berbeda penyebutan.

Selain ikan ada juga pemanfaatan susu kerbau menjadi bahan makanan yang dibuat seperti keju. Yaitu gula puan, gula puan merupakan makanan yang kelak pada zaman kesultanan Palembang Darussalam itu menjadi makanan favorit para raja Palembang dan harganya sekarang lumayan mahal makanan tersebut dibuat dari bahan baku susu kerbau yang dimasak dengan cara di aduk dan setelah matang itu warna berubah menjadi kecoklatan dan rasanya pun manis. Dari kedua uraian tersebut, dapat ditarik kesimpulan bahwa sistem pengelolaan makanan di daerah pantai Timur Sumatera Selatan salah satu termasuk dari budaya Austronesia dari segi pengelolaan makanan yang diawetkan secara tradisional yang sudah di bawa oleh bangsa Austronesia ke pantai Timur Sumatera Selatan dan sampai sekarang tradisi tersebut masih digunakan.

\section{SIMPULAN}

Budaya Autronesia yang terdapat di pantai Timur Sumatera Selatan berupa peternakan kerbau, ladang, dan teknologi perkapalan, kerbau memiliki makna salah satunya terdapat unsur didalam sistem dualisme dimana alam semesta ini dibagi atas dua hal atau dua golongan yang saling bertentangan satu sama lainnya, antara lain dunia bawah dan atas, laki laki dan wanita, alam nyata dan maya dan sebagainya.
Begitu juga dengan cara pandang masyarakat masa lalu terhadap kerbau yaitu kerbau dipandang dari dua sisi yaitu sisi fisik dan non fisik.

\section{DAFTAR PUSATAKA}

Asnan, Gusti. 2006. Dunia Maritim Pantai Barat Sumatera. Yogyakarta: Ombak.

Hadi, Miftahul IImi. 2012. Pengenalan Benua Di Asia. Bandung: Mitra Utama.

Herimanto. 2012. Sejarah Indonesia Masa Pra Aksara. Yogyakarta: Ombak

Koenjaraningrat. 2009. Pengantar IImu Antropologi. Jakarta: Rineka Cipta.

Marsden, William. 2013. Sejarah Sumatera. Jakarta: Komunitas Bambu.

Munandar, Agus Aris. 2012. Kebudayaan Austronesia Sebagai Akar Peradaban Nusantara: Ornamen Pada Nekara Dan Artefak Perunggu Lainnya. Depok: Departemen Arkeologi FIB UI.

Pusponegoro, Marwati Djoened.dkk. 2010. Sejarah Indonesia II. Jakarta: Balai Pustaka.

Samanto. Ahmad Y. Dan Abdurahman, Oman. 2011. Peradaban Atlantis Nusantara. Jakarta: UFUK Perss.

Soekmono. 1973. Pengantar Sejarah Kebudayaan 1. Yogyakarta: Kanisius.

Sriyono. 2014. Geologi dan Geomorfologi Indonesia. Yogyakarta: Ombak.

Supriyanto. 2013. Pelayaran dan Perdagangan Di Pelabuhan Palembang. Yogyakarta: Ombak.

Siddhayatra, 2014. Volume 19 nomor 2. Palembang: Balai Arkeologi Sumsel.

Utomo, Bambang Budi. 2016. Peradaban Masa Lalu Sumatera Selatan. Palembang: Balai Arkeologi Sumsel.

Wiradnyana, ketut. 2011. Pra Sejarah Sumatera Bagian Utara Kontribusinya Terhadap Kebudayaan Hindhu. Jakarta: Yayasan Pustaka Obor Indonesia. 